\title{
E-banking and Customer Satisfaction with Banking Services
}

\author{
Andreea-Daniela Moraru \\ Faculty of Economic Sciences, Ovidius University of Constanta, Constanta, Romania \\ Cristina Duhnea \\ Faculty of Economic Sciences, Ovidius University of Constanta, Constanta, Romania
}

\begin{abstract}
The set-off of the financial crisis in 2007 , as well as the natural dynamics of the banking sector, have determined a fierce competition within the banking industry.

The Romanian banking system developed rapidly in terms of profitability and rhythm of credit growth up to 2007, and therefore credit institutions did not make efforts to investigate and support customer satisfaction through concerted actions, since the economic growth period created and maintained the phenomenon commonly referred to as "the client searches for the bank". Starting with 2008, however, the prospects have changed significantly due to the drastic reduction of the consumption of banking products, especially loan products. Credit institutions were therefore forced to rethink their promotion strategies and pay more attention to all elements that impact customer satisfaction including digitalization of the banking products without additional costs.

Under these circumstances, banks are preoccupied, more than ever, with customer satisfaction.

The particular nature of the banking activity limits the possibilities for banks to differentiate their offer of products and services (Ilie et al., 2017). Bearing in mind that in the end all organizations strive to obtain customer loyalty, banks' concern with customer satisfaction appears as a natural and legitimate preoccupation.

Although the concept of satisfaction was introduced several decades ago by Cardozo (1965), a consensus regarding its definition has not yet been reached. Some authors view satisfaction as a process (Hunt, 1977, Tse and Wilton, 1988), while others regard it as an outcome (Howard and Sheth, 1969). Although a generally accepted definition has not yet been developed, numerous models including determinants or antecedents of customer satisfaction are available in the dedicated literature. As in the case of the definition of customer satisfaction, consensus has not been reached regarding the determinants or antecedents of customer satisfaction either.

The focus of this paper is to grasp the importance of e-banking within the general satisfaction of customers with regard to banking services.

Following an ample literature review, we selected five categories of customer satisfaction determinants with bank services: convenience, environment, quality, tariffs, and e-banking, each comprising several sub-criteria. We then employed a descriptive quantitative research, in Constanta County (South-East Romania), during November and December 2016. The research tool was a questionnaire comprising three main sections: a general socio-demographic section, a section dedicated to the assessment of the general customer satisfaction level with bank services, and a third section focused on assessing the five categories of customer satisfaction determinants in terms of bank services. Five-point semantic differentials (from 1 -very unsatisfied to 5 - very satisfied) were used in order to assess the general satisfaction level with banking services as well the satisfaction level with each of the 16 criteria.
\end{abstract}

Keywords

Customer satisfaction, banking services, service quality, customer loyalty.

\section{Introduction}

The Romanian banking system has undergone two distinct stages over the past 17 years in terms of how credit institutions have levelled on customer satisfaction and infrastructure modernization in order to offer e-banking and mobile banking services as an integral of the banking products offer. Until 2007, the range of the banking 
services offered to customers was part of the traditional lending and saving products and the most important aspect in relations with the clients was the product. Starting with 2008, with the manifestation of the effects of the international financial crisis, the banking system entered another stage - the refining of the banking products and services offered in order to maintain customer satisfaction and to achieve their retention in the conditions of a drastic reduction of the consumption of such products and services.

The performance indicators of the Romanian banking system from 2007 to 2009 show unequivocally the moment when the concern for the improvement of the offer and the interest for the elements that affect the satisfaction of the clients changed the operational and marketing strategies in the Romanian banking market, as can be seen in the table below:

Table 1 Selected performance indicators of the Romanian banking system

\begin{tabular}{l|c|c|c}
\hline \multicolumn{1}{c|}{ Indicator } & $\mathbf{2 0 0 7}$ & $\mathbf{2 0 0 8}$ & $\mathbf{2 0 0 9}$ \\
\hline $\begin{array}{l}\text { Growth ratio of non- } \\
\text { governmental loan- in real } \\
\text { terms }\end{array}$ & $50.5 \%$ & $25.8 \%$ & $-3.6 \%$ \\
\hline $\begin{array}{l}\text { Overdue receivables/total } \\
\text { assets }\end{array}$ & 0.17 & 0.29 & 1.01 \\
\hline $\begin{array}{l}\text { Overdue receivables / total } \\
\text { equity }\end{array}$ & 1.6 & 3.19 & 11.78 \\
\hline Profitability - ROA & 1.01 & 1.56 & 0.25 \\
\hline Profitability - ROE & 9.43 & 17.04 & 2.89 \\
\hline
\end{tabular}

Source: Authors' compilation using data from the National Bank of Romania Reports - years 2007, 2008, and 2009

The research developed in this article aims at identifying the influence of five categories of customer satisfaction determinants with banking services in the South East Romania region. The article is organized as follows: a brief review of the literature on customer satisfaction in general and customer satisfaction with banking services, research methodology (data, the structure of the sample, data analysis), and conclusions.

\subsection{Customer satisfaction with banking services - literature review}

Introduced several decades ago by Cardozo (1965), the researchers and practitioners have not yet reached a consensus regarding its definition. Some authors view satisfaction as a process (Hunt, 1977, Tse \& Wilton, 1988), while others regard it as an outcome (Howard \& Sheth, 1969). As the complexity of the economic activity augmented, the study on satisfaction grew rapidly in the 1970's, as more than 500 studies were carried out regarding customer satisfaction (Hunt, 1982, cited by Clinton \& Wellington, 2013).

In these studies were crystallized several categories of theories that have attempted to explain how it works and what influences the customer satisfaction. Reviewing the theories of satisfaction from literature, Clinton and Wellington (2013) concluded that the most documented and confirmed by different research studies are: assimilation theory, contrast theory, assimilation-contrast theory, and negativity theory. Isac and Rusu (2014), citing Peyton et al. (2003) and based on a synthesis by Vavra (1997) considered five categories of such theories, adding to those previously mentioned the theory of hypothesis testing.

The best-known theory and widely accepted by specialists is the expectancy disconfirmation paradigm developed by Oliver (1980), Churchill and Surprenant (1982) or Tse and Wilton (1988), which establishes that consumer satisfaction can be viewed as the difference between expected and perceived product performance, expectations as predictions of future performance.

Another aspect that the specialised literature highlighted was the need to support this multitude of theories with empirical evidence. Johnson and Fornell (1991, p.23) emphasized "it is important that future research adopts an empirical approach that recognizes both the nature of the satisfaction construct and the measurement problems associated with satisfaction research [...] As a latent construct, satisfaction can be measured proximally (though not equated) with observable indicators".

As customer satisfaction issues gained ground in the scientific studies, researchers have looked for the most appropriate investigative methods and created various systems of indicators in search of the most appropriate combination for the product/service considered. Several authors such as Isac and Rusu (2014) or Spreng and Page (2003) have synthesized the most commonly used methods to investigate consumer satisfaction. These include difference score, direct effects model, better than / worse than, standard percept disparity, additive differential model, etc. They are all used and each has its own advantages and disadvantages, but the choice must be made taking into account the particularities of the product/service on the one hand and the category of consumers targeted, on the other hand. 
If we refer to the satisfaction of the banking services consumers, the specialized literature shows that, on the one hand, the generally developed consumer satisfaction theories have been applied in various studies at different levels (of a single bank, of a region or of a national economy). On the other hand, it was necessary to customize the methods used and the selection of the determinants in accordance with the specificity of the services and the banking industry. Belas and Gabcova (2016) synthetized the visions expressed by different authors. Some viewed a certain characteristic as being essential in determining the level of customer satisfaction while others, on the contrary, stated that highlighting only one determinant can be irrelevant, and that the relations between customer satisfaction and its determinants tend to be nonlinear, to influence each other or to be found only in some segments.

The analysis of customer satisfaction in the banking industry of Romania has been the subject of several studies but the investigation was mostly limited to either one bank (not necessarily to its entire national network) or to a city/ region. Bente (2013) conducted a study regarding consumer satisfaction with Volksbank Oradea using a SERVQUAL method and identified the safety as the most important determinant. Bena (2010) investigated through a survey the level of customers' satisfaction with a specific Romanian bank from Bucharest, while Micuda and Cruceru (2010) used SERVQUAL method to investigate customer satisfaction with banking services in the city of Pitesti. Radomir et al. (2011) developed a more extensive research regarding banking services customer satisfaction considering a single bank, Ro Bank, with a targeted geographical location in Cluj-Napoca. The authors investigated three dimensions in relation with customer satisfaction: human resources, convenience and efficiency, and tangible aspects, and found that all of them are in a positive relationship with customer satisfaction. In order to deepen the research, the study employed the technique of "more than/less than", often encountered in the international literature.

The scarcity of the research conducted to determine the level of customer satisfaction and its determinants in the Romanian banking industry is the argument that supported our research and the importance of our findings.

\section{Research methodology}

\subsection{The data}

Following a close review of the literature on customer satisfaction in general and specifically on customer satisfaction with banking services, as well as the related concepts of service quality and customer loyalty, we decided upon five main categories of determinants that impact customer satisfaction with banking services: convenience, environment, quality, tariffs, and e-banking, and in the case of four categories of determinants there were identified subcategories (Table 2).

Table 2 Customer satisfaction with services - determinants

\begin{tabular}{|c|c|c|c|c|c|}
\hline Determinant & Convenience & Quality & Environment & Tariffs & E-banking \\
\hline Subcategories & $\begin{array}{l}\text { 1. bank location } \\
\text { 2. distance to the bank } \\
\text { 3. availability of parking } \\
\text { spaces } \\
\text { 4. ATM availability }\end{array}$ & $\begin{array}{l}\text { 1. trust } \\
\text { 2. prompt reaction of } \\
\text { personnel } \\
\text { 3. safety of operations } \\
\text { 4. solicitude }\end{array}$ & $\begin{array}{l}\text { 1. furniture } \\
\text { 2. equipment } \\
\text { 3. cleanness } \\
\text { 4. personnel physical } \\
\text { appearance } \\
\text { 5. bank atmosphere }\end{array}$ & & $\begin{array}{l}\text { 1. availability of } \\
\text { e-banking services } \\
\text { 2. e-banking services } \\
\text { performance }\end{array}$ \\
\hline
\end{tabular}

Source: Authors' contribution

A descriptive quantitative analysis was conducted in Constanta County, during November and December 2016. The data were collected using a questionnaire as a research tool. The questionnaires were randomly distributed, and out of 750, 667 were returned filled in. After eliminating the ones that were incomplete, the research was finally conducted on 643 questionnaires, using IBM SPSS Statistics 23.
The research instrument, a questionnaire, comprised several sections: a socio-demographic section, a section focusing on assessing the general level of satisfaction with banking services as well as the satisfaction with several service categories, and a section focused on assessing the five categories of customer satisfaction determinants in terms of bank services. The general level of satisfaction, as well as the customer satisfaction with different categories of 
services and the satisfaction with each of the 16 criteria listed in table 1 were assessed using a five-point semantic differential (from 1 - very unsatisfied to 5 - very satisfied).

The research presented in this paper is part of a more ample research focused on assessing customer satisfaction with banking services. The collected data made the object of a large study aimed at simulating customer satisfaction in banking services using an artificial neural network and was already published in 2017 - The hierarchical determination of customer satisfaction with banking services using an artificial neural network, by authors Ilie, Moraru, and Ghita-Mitrescu (2017). In this paper, the focus is on e-banking services and the impact ebanking services have on the general level of customer satisfaction.

\subsection{The structure of the sample}

The structure of the sample is presented in Figures 1-7.

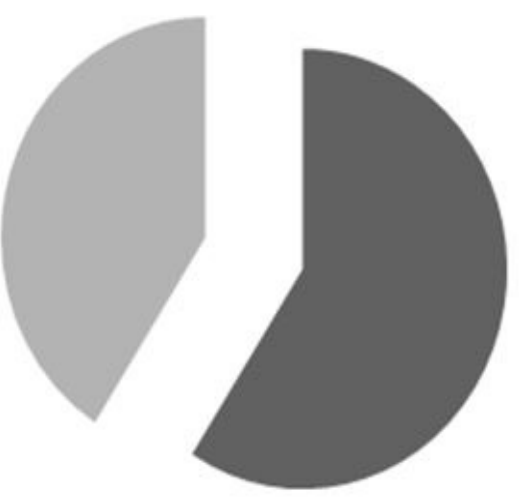

ale Mali Female

Figure 1 Sample structure - Gender Source: the authors' processing

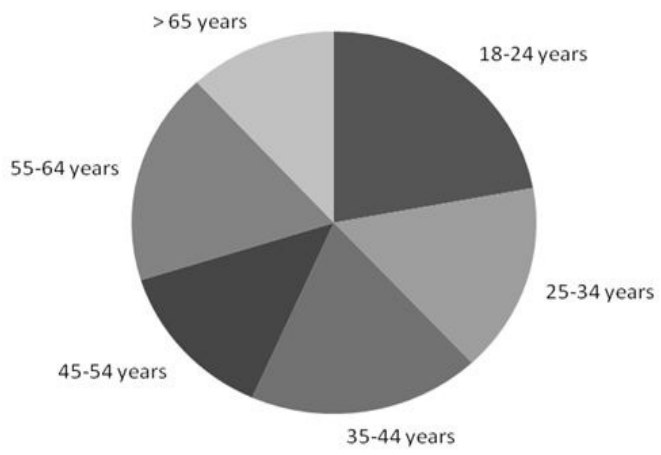

Figure 2 Sample structure - Age Source: the authors' processing

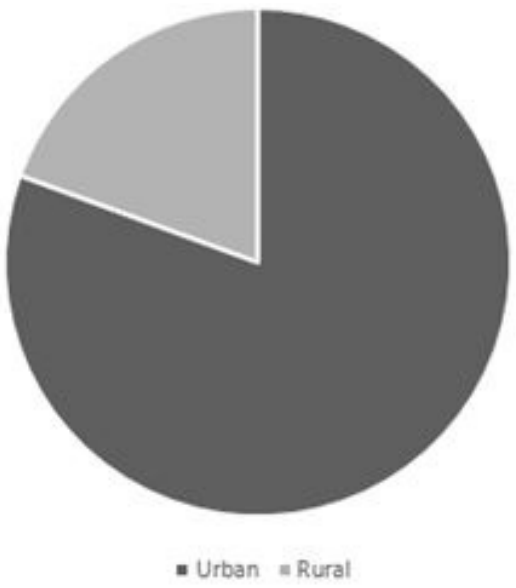

Figure 3 Sample structure -Residence Source: the authors' processing

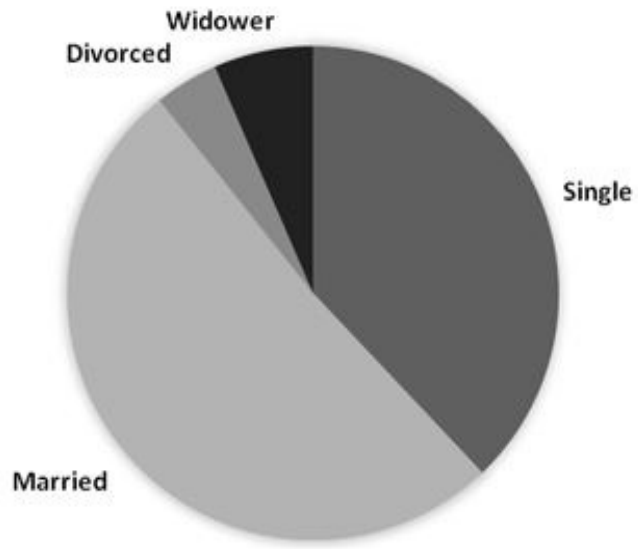

Figure 4 Sample structure - Marital status Source: the authors' processing

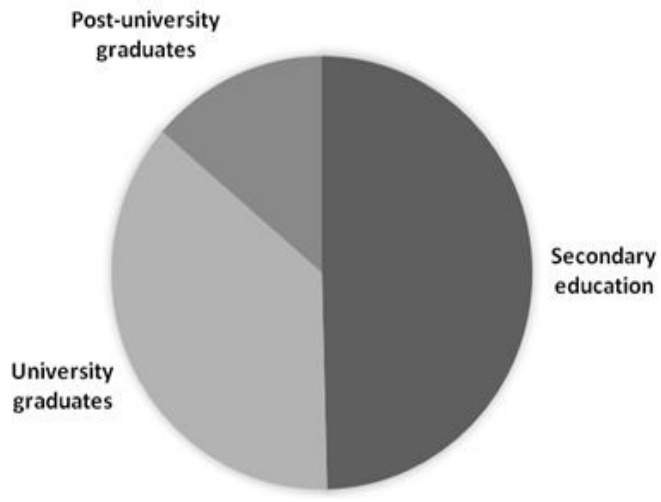

Figure 5 Sample structure - Education Source: the authors' processing 


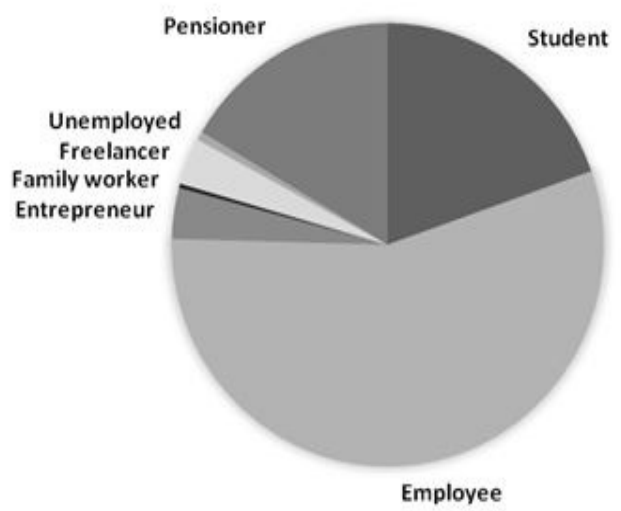

Figure 6 Sample structure - Professional status Source: the authors' processing

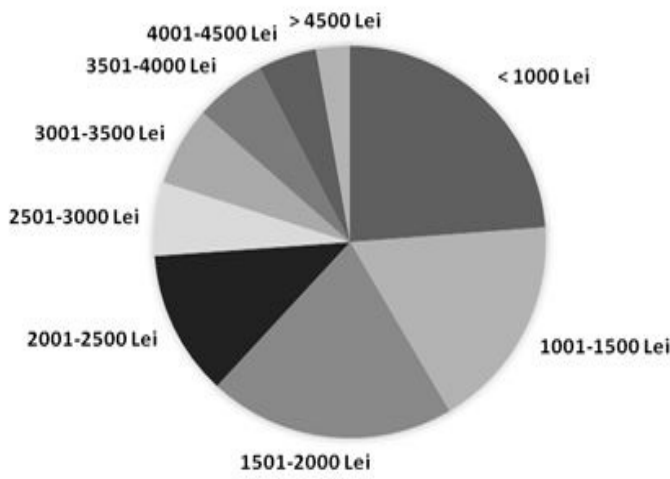

Figure 7 Sample structure - Average monthly income Source: the authors' processing

\subsection{Data analysis}

The duration of the collaboration with the bank is as follows: between 5 and 10 years (39.2\%), less than $5(35.8 \%)$, between 11 and 15 years $(13.2 \%)$, more than 15 years $(11.8 \%)$.

Descriptive statistics regarding the general level of satisfaction and levels of satisfaction with different categories of banking services are presented in table 3 .

Table 3 Descriptive statistics

\begin{tabular}{|c|c|c|c|c|c|}
\hline & 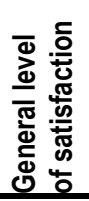 & 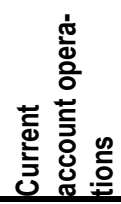 & 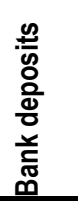 & 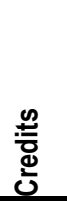 & 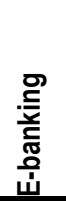 \\
\hline Mean & 4.09 & 4.11 & 3.7 & 3.67 & 4.08 \\
\hline $\begin{array}{l}\text { Std. } \\
\text { Devia- } \\
\text { tion }\end{array}$ & .649 & .690 & .835 & .809 & .874 \\
\hline $\begin{array}{l}\text { Mini- } \\
\text { mum }\end{array}$ & 1 & 1 & 1 & 1 & 1 \\
\hline $\begin{array}{l}\text { Maxi- } \\
\text { mum }\end{array}$ & 5 & 5 & 5 & 5 & 5 \\
\hline
\end{tabular}

\begin{tabular}{|c|c|c|c|c|c|}
\hline $\begin{array}{l}\text { Skew- } \\
\text { ness }\end{array}$ & -.874 & -1.314 & -1.186 & -.770 & -1.127 \\
\hline $\begin{array}{l}\text { Std. } \\
\text { Error of } \\
\text { Skew- } \\
\text { ness }\end{array}$ & .096 & .096 & .123 & .145 & .116 \\
\hline $\begin{array}{l}\text { Kurto- } \\
\text { sis }\end{array}$ & 3.083 & 4.413 & 2.366 & .877 & 1.784 \\
\hline $\begin{array}{l}\text { Std. } \\
\text { Error of } \\
\text { Kurto- } \\
\text { sis }\end{array}$ & 192 & .192 & .245 & .288 & .232 \\
\hline
\end{tabular}

\subsection{Testing the research hypotheses}

Several research hypotheses were formulated and subsequently tested.

$\mathrm{H}_{1}$. There is a strong correlation between the satisfaction with e-banking and the general level of satisfaction.

We tested the correlation between the two variables and the results indicate that they are strongly correlated, $r(641)=.357, p<.01$.

$\mathrm{H}_{2}$. The assessment of the satisfaction with ebanking services differs based on gender.

All assumptions have been met (normality of the dependent variable, homogeneity of variances), so an independent sample t test can be performed.

The test results, $t(438)=-.436, p=.663$, lead to the acceptance of the null hypothesis.

$\mathrm{H}_{3}$. There are statistically significant differences in the satisfaction with e-banking services between age groups.

All assumptions have been met (normality of the dependent variable, homogeneity of variances, and independence of observations) and one-way ANOVA can be performed.

There is a statistically significant difference between groups as determined by the one-way $\operatorname{ANOVA}(F(5,434)=3.34, p=.006)$.

A Tukey post hoc test revealed that the level of satisfaction with e-banking services is significantly lower for the age group over 65 years old $(3,60+/-.503, \mathrm{p}=0.28)$ compared to the age group 18-24 (4.24+/- .945).

$\mathrm{H}_{4}$. The assessment of the satisfaction with ebanking services differs based on residence environment (rural/urban).

All assumptions have been met (normality of the dependent variable, homogeneity of variances), so an independent sample $t$ test can be performed.

The test results are: $t(438)=.854, p=.393$; therefore, we accept the null hypothesis. 
$\mathrm{H}_{5}$. There are statistically significant differences in the satisfaction with e-banking services between professional groups.

All assumptions have been met (normality of the dependant variable, homogeneity of variances, and independence of observations) and one-way ANOVA can be performed.

There is a statistically significant difference between groups as determined by one-way ANOVA $(\mathrm{F}(6,433)=4.71, p=.000)$.

$\mathrm{H}_{6}$. There are statistically significant differences in the satisfaction with e-banking services between income groups.

All assumptions have been met (normality of the dependant variable, homogeneity of variances, and independence of observations) and one-way ANOVA can be performed.

There is a statistically significant difference between groups as determined by one-way $\operatorname{ANOVA}(\mathrm{F}(8,431)=1.99, p=.046)$.

\section{Conclusions}

The importance of the customer satisfaction in banking services is the result on the one hand, of the stronger dynamics of the industry. On the other hand, as stated by Belas and Gabcova (2016), in this business sector, characterized by an increased competition, an efficient management of selling additional products and services to existing satisfied customers represents a significant opportunity to improve the financial performance of a bank.

The research conducted revealed that overall customer satisfaction with banking services and customer satisfaction with e-banking services are strongly correlated, thus pointing out the importance of e-banking services. The research results also indicated that the assessment of the satisfaction with e-banking services does not differ based either on gender, or on residence environment (rural/urban). However, the level of satisfaction with e-banking services is significantly lower for the age group over 65 years old compared to other age groups. Our findings are in line with previously conducted studies such as Gikandi and Bloor (2010) or Mukhtar (2015). In addition, it was revealed that there are statistically significant differences in the satisfaction with e-banking services between professional groups, as well as between income groups.

Considering the importance of e-banking services in the overall assessment of satisfaction with banking services and given the impact of custom- er satisfaction in the increasingly competitive banking sector, the conducted research may represent a starting point for future studies regarding customer satisfaction with banking services both at national and international level. SM

\section{References}

Belás, J. \& Gabčová, L. (2016). The relationship among customer satisfaction, loyalty and financial performance of commercial banks, Ekonomie a Management, volume $\mathrm{XIX}$, issue 1.

Bena, I. (2010). Evaluating customer satisfaction in banking services, Management \& Marketing, 5 (2), 143-150.

Bente C. (2013). The Quality Of Banking Services - A Basic Premise Of A Bank Sustainability, Annals of Faculty of Economics, University of Oradea, Faculty of Economics, 1 (2), 430-439.

Cardozo, R. (1965). An experimental Study of Customer Effort, Expectation, and Satisfaction, Journal of Marketing, Research, 2 (8), 244-249.

Churchill, G.A.J. \& Surprenant, C. (1982). An investigation into the determinants of customer satisfaction, Journal of Marketing Research, 19 (4), 491-504.

Clinton, A. \& Wellington, T., (2013). Theoretical Framework of Users' Satisfaction/Dissatisfaction Theories and Models, 2nd International Conference on Arts, Behavioral Sciences and Economics Issues (ICABSEl'2013) Dec. 17-18, 2013 Pattaya (Thailand).

Gikandi, J. \& Bloor, C., (2010). Adoption and effectiveness of electronic banking in Kenya. Journal of Electronic Commerce Research and Applications, 9, 277-282.

Johnson, M. D. \& Fornell, C. (1991). A framework for comparing customer satisfaction across individuals and product categories. Retrieved January 102018 from Cornell University, School of Hotel Administration site: http://scholarship.sha.cornell.edu/articles/684

Howard, J.A. \& Sheth, J. (1969). The theory of buyer behavior. New York: Wiley.

Hunt, H. K. (1977). Overview and Future Research Directions. In H. K. Hunt, Conceptualization and Measurement of Consumer Satisfaction and Dissatisfaction (pp. 455-488). Cambridge: Marketing Science Institute.

Ilie, M., Moraru, A.D. \& Ghita-Mitrescu, S., (2017). The hierarchical determination of customer satisfaction with banking services using an artificial neural network, Transformations in Business \& Economics, 16 (41A), 401-420.

Isac, F.L. \& Rusu, S. (2014). Theories of consumer's satisfaction and the operationalization of the expectation disconfirmation paradigm, Annals of the "Constantin Brâncuşi" University of Târgu Jiu, Economy Series, Issue 2/2014.

Micuda, D. \& Cruceru, G. (2010). Testing SERVQUAL dimensions on the Romanian banking sector, Proceedings of the International Conference on RISK MANAGEMENT, ASSESSMENT and MITIGATION, Bucharest, Romania, Retrieved April 2010 from http://www.wseas.us/elibrary/conferences/2010/Bucharest/RIMA/RIMA-00.pdf

Mukhtar, M. (2015). Perceptions of UK Based Customers toward Internet Banking in the United Kingdom, Journal of Internet Banking and Commerce, 20 (1). 
National Bank of Romania - Annual reports for 2007, 2008, and 2009.

Oliver, R.L. (1980). A Cognitive Model of the Antecedents and Consequences of Satisfaction Decisions, Journal of Marketing Research, 17 (11), 460-469.

Radomir, L., Wilson, A. \& Scridon, A.M. (2011). Improving bank quality dimensions to increase customer satisfaction, Management Marketing Journal, IX (1), 126-148.

\section{$\triangle$ Correspondence}

\section{Andreea-Daniela Moraru}

Faculty of Economic Sciences, Ovidius University of Constanta 124 Mamaia Av., 900527, Constanta, Romania

E-mail:moraru.ad@gmail.com
Spreng, R.A. \& Page, T.J. Jr. (2003). A Test of Alternative Measures of Disconfirmation, Decision Sciences, 34 (1), 31-62.

Tse, D.K. \& Wilton, P.C. (1988). Models of Consumer Satisfaction Formation: An Extension. Journal of Marketing Research, 25 (2), 204-212 